\title{
The Role of a Bibliographer in a Japanese Collection
}

By YUKIHISA SUZUKI

$\mathrm{T}$ HE WORK OF A BIBLIOGRAPHER in a research library of approximately 110 ,000 Japanese volumes ${ }^{1}$ is both diversified and challenging. Essentially, his job is to acquire most effectively the books and other materials needed, or expected to be needed, for instructional and research purposes in Japanese studies. Perhaps in the routine phases of his work-for example, checking, keeping desiderata files, and processing orders-his work may not differ drastically from that of a bibliographer in other collections. However, as may be imagined, various factors involved in acquiring Japanese materials present many problems. The bibliographer is handling materials published in one of the most complicated of languages and he is dealing with native dealers. Moreover, the business customs of the United States and those of Japan vary widely. For the verification and examination of materials selected, the librarian has to rely on a special kind of bibliographical material, and, at the same time, he suffers from the lack of many types of bibliographical tools established for Western-language publications.

Perhaps what makes a Japanese bibliographer's role different from that of his counterpart in a library concerned with Western languages is that he has to take more initiative in selecting materials. In consultation with the head of

1 For a description of the collection see: Elizabeth Huff, "Far Eastern Collection in the East Asiatic Li. brary of the University of California," Far Eastern Quarterly, XIV (1955), 443-46. Also, for a general survey of the Oriental collections in the United States see: G. Raymond Nunn and Tsuen-Hsuin Tsien, "Far Quarterly, XXIX (1959), 27-42.

The author is very grateful to Dr. Elizabeth Huff for her encouragement and special assistance in preparing this article. Gratitude is also due to Mr. Marion A. Milczewski and Mr. Everett T. Moore for valuable suggestions.
Mr. Suzuki is Japanese Bibliographer in the East Asiatic Library, University of California, Berkeley.

the collection he selects about 80 per cent of the Japanese books annually acquired. Rather than merely receiving orders and checking on the requested items, he has to go into the market and hunt for the materials which, in his judgment, will be necessary or useful for research in Japanese studies. In the East Asiatic Library, coverage is sought in all the intellectual fields, especially in the social sciences, bibiography, language and literature, and the arts. All the publications of presumed research value are sought and studied as much as possible before final orders are placed.

The first major hurdle the Japanese bibliographer faces in his work is the enormous number of monographs and periodicals published each year in Japan. In 1956 the number of monographs published was 24,541 , of which 14,983 were new titles. In 1957 the number of monographs published reached a record of 25,299 , of which 14,026 were new titles. The number for 1958 showed a slight decrease; but, still, with 24,983 titles, of which 14,258 were new, Japan surpassed Great Britain, which published 22,143, and the United States, which published 13,462 books in the same year. Thus in terms of quantity Japan is really the world's leading publishing country. Table 1 shows the distribution by subject of monographic titles published in Japan during the nine-year period 1950 . 1958. 
TABLE 1

Subject Distribution of Monographs Published in Japan, 1950-1958*

\begin{tabular}{|c|c|c|c|c|c|c|c|c|c|}
\hline SUBJECT & 1950 & 1951 & 1952 & 1953 & 1954 & 1955 & 1956 & 1957 & 1958 \\
\hline 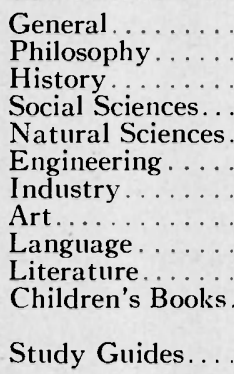 & $\begin{array}{r}87 \\
731 \\
308 \\
2,242 \\
904 \\
857 \\
603 \\
783 \\
549 \\
2,770 \\
1,408\end{array}$ & $\begin{array}{r}182 \\
814 \\
465 \\
2,344 \\
1,202 \\
1,193 \\
749 \\
842 \\
580 \\
3,754 \\
1,388\end{array}$ & $\begin{array}{r}256 \\
820 \\
546 \\
2,435 \\
1,383 \\
1,349 \\
826 \\
1,002 \\
557 \\
4,017 \\
4,115 \dagger\end{array}$ & $\begin{array}{r}316 \\
938 \\
671 \\
2,702 \\
1,795 \\
1,627 \\
1,091 \\
999 \\
694 \\
4,798 \\
4,662 \dagger\end{array}$ & $\begin{array}{r}273 \\
879 \\
708 \\
2,457 \\
1,397 \\
1,373 \\
776 \\
996 \\
646 \\
4,836 \\
5,496 \dagger\end{array}$ & $\begin{array}{r}405 \\
1,004 \\
866 \\
2,592 \\
1,327 \\
1,468 \\
900 \\
1,127 \\
703 \\
5,815 \\
3,260 \\
2,186\end{array}$ & $\begin{array}{r}423 \\
1,099 \\
986 \\
2,962 \\
1,481 \\
1,654 \\
1,079 \\
1,344 \\
791 \\
6,356 \\
3,551 \\
2,815\end{array}$ & $\begin{array}{r}357 \\
1,028 \\
995 \\
3,132 \\
1,474 \\
1,699 \\
1,165 \\
1,313 \\
921 \\
6,128 \\
4,042 \\
3,045\end{array}$ & $\begin{array}{r}395 \\
1,043 \\
1,103 \\
3,313 \\
1,495 \\
1,721 \\
1,225 \\
1,182 \\
902 \\
6,155 \\
3,397\end{array}$ \\
\hline Total. & 13,009 & 15,536 & 17,306 & 20,293 & 19,837 & 21,653 & 24,541 & 25,299 & 24,983 \\
\hline
\end{tabular}

* Based on the statistics in Shuppan nyusu, No. 447, (May 1, 1959), p. 2. The classification of the publications is according to the Nippon Decimal System.

+ This figure represents the totals for Children's Books and Study Guides.

It will be evident that it is not an easy task to select out of so many titles the materials to support local teaching and research in the culture of Japan and to maintain an over-all, balanced collection. A second handicap the bibliographer faces is distance from his dealers and publishers. He has to deal with Japanese bookmen over six thousand miles away, and this involves much time and careful effort. Any mistake by either party introduces extra expense.

One way to maintain close connection with the dealers is to exchange correspondence in the Japanese language. No matter how anxious they may be to do business with a foreign institution, if they have to carry out business in a foreign language, not only will it discourage them, but, even if they wish to carry it out for a long duration, it will hamper their efficiency. Orders may be written or typed in romanized transcription, but the titles should be accompanied with characters. The romanized transcription without the characters is very often not intelligible to the Japanese. They cannot, nor can we at times, decipher all romanized transcriptions. Likewise, no American book dealer would be able to handle an order if a Japanese sent the orders for English titles in the Japanese katakana transcription. If the dealers can write letters in their native language, they also may be able to help the bibliographer on some intricate bibliographical questions.

The bibliographer has to utilize every possible source of information, in such materials as are available, regarding the contents and value of the publications to be acquired. What, then, are the most ready sources for information on current publication? Probably the Shuppan nyūsu [The Publication News]-quite similar to the Publishers' Weekly - which is published three times a month, will give the best picture of current Japanese publications. The journal is indexed semiannually. If the library is to circulate any book lists among the faculty for their selections of current Japanese publications, this will be the best choice. Since the Japanese collection is primarily for the faculty and graduate students in Japanese studies, it is extremely important to provide some sort of mechanism to show a reflection of academic interests. Circulating publishers' journals or dealers' catalogs is recommended. The 
bibliographer should not overwhelm the faculty with too many lists. No matter how slow circulation of the lists among the faculty may be, it gives a useful channel for understanding where their current interest and research is centered. Of course, there are various kinds of recommendations; some reflecting research needs and others only general interest.

Another useful source for new Japanese publications is the Nōhon shühōKokunai shuppanbutsu mokuroku [Weekly List of Newly Deposited Titles; Catalog of Publications Issued Inside Japan]. It is published weekly by the National Diet Library of Japan, and the items listed are arranged according to the Japan Decimal System; publications published a few years before are often listed. The publications listed in the weekly issues are not the only ones for sale; also available are numerous government, institutional, society, and privately printed publications. For each title brief descriptive information is given. This is a valuable source for identifying what is currently being published, but it also sometimes proves to be a source of frustration, since some of the governmental and institutional publications may not be purchased even with the persistent efforts of capable dealers. Through the Seifu kankōbutsu mokuroku, a monthly journal of Japanese government publications, the bibliographer learns the titles of the various monographs being published by governmental agencies. It is not easy to acquire some of them, and the bibliographer may have to try all possible means for acquisition, such as writing directly to the governmental offices, asking the National Diet Library for its assistance, or writing to dealers. The same thing applies to institutional and society publications.

For critical and descriptive reviews of new titles, the Nihon dokusho shimbun and the Tosho shimbun, both weekly newspapers of book reviews and articles, are indispensable. The reviews are enlightening, and the bibliographer is also given information on the publishing business in Japan. One feature which is sometimes quite useful is the occasional listing of books in certain fields which the editors consider to be fundamental and important. For new books there are also such dealers' journals as the Nippan tsūshin and the Shinkan nyūsu, published by two leading jobbers in Tokyo, the Nippon Shuppan Hambai Kabushiki Kaisha and the Tōkyō Shuppan Hambai Kabushiki Kaisha respectively, but they usually add very little to the information included in the Shuppan nyüsu. The Shuppan nenkan [Publication Yearbook], which is published about July of each year, can be used effectively to see whether or not there has been any serious omission in the selection of publications in the previous year, and it is an indispensable source of information on the Japanese publishing business in general. In addition, the bibliographer receives numerous brochures from dealers and publishers.

If the bibliographer is charged with the responsibility of selecting materials on his own initiative, he has to be familiar with contemporary trends in the fields in which he is to make the book selection. It is not possible to read all the journals in the social sciences, but by skimming through some of the journals in the various fields, such as the Rekishigaku kenky $\bar{u}$ [The Journal of Historical Studies], the Kokka Gakkai zasshi [The Journal of the Association of Political and Social Sciences], the Ajiya kenkyū [Asiatic Studies], the Bungaku [Literature], the Shigaku zasshi [The Historical Journal of Japan], the Shakaigaku hyoron [Japanese Sociological Review], the Hitotsubashi ronsõ [The Hitotsubashi Review], and the Töyōshi kenkyū [The Journal of Oriental Researches], he can build up his knowledge on current studies and gain what may be called "enlightened intuition" in book selection. If the bibliographer has to select books for 
the library, the work is a challenge to his knowledge of intellectual activities. Many academic journals print book reviews by scholars and report news and notices in the respective fields, and some of them annually print extensive articles surveying the academic accomplishment in the previous year. That provides the bibliographer with a way to review his selection during these years. The sooner he discovers an omission and fills in a gap, the better.

If the bibliographer can also act as official host, or if he has at least a chance to meet Japanese visitors, the opportunity can be well used as a source of getting first-hand information on Japanese publications, both old and new. Meeting foreign visitors provides a wonderful opportunity to show the "sparks" of American librarianship in action and the fine collection of materials the visitors' country has produced, but the bibliographer will also have a chance to ask for professional evaluation on certain publications, trends in special fields, or suggestions for improvement of the collection. Rather than being overwhelmed with the explanation of the size, history, service, characteristics, special features, or budget of the library, the visitors will appreciate such gestures of friendliness and humility. In order to let them appreciate fully what they see, they have first to be made to feel at home in the library, and asking them about materials in their respective fields may serve the purpose. It will also give the bibliographer a chance to thank them cordially for the materials the library has received by exchange, if such an arrangement is already set up, or to ask their cooperation in the future for the development and improvement of the collection. If an exchange arrangement has not been set up, it will give a good chance to investigate the possibility of opening one on a mutually satisfactory basis.

In regard to old books, the bibliographer has to rely on two means; one is checking in the dealers' catalogs and the other is sending out a search list. Big dealers in Tokyo, such as the Isseidō, the Inoue Shoten, the Rinrōkaku, the Kyokutō Shoten( also called the Far Eastern Book-sellers), the Gannando Shoten, the Bunsei Shoin, the Japan Publications Trading Company, and some of the dealers in Kyoto area, such as the Ibundō and the Rinsen Shoten, regularly issue catalogs of both current imprints and old, used books. Some of them voluntarily send catalogs of dealers with whom they are on friendly terms and offer the service of procuring the materials listed in these catalogs. They usually send them to the library by air mail. A dealer once mentioned that it is practically impossible to acquire important and interesting items two weeks after the catalogs are issued. This is a very serious handicap for any oriental collection outside of Japan, since it takes about four days, even if the catalogs are mailed immediately after they are printed, to reach most of the oriental collections. Probably it will take another three or four days, unless the items selected are extremely important and urgently sought after, before the bibliographer or his assistants can finish checking and prepare the order forms. Another several days will be spent before they go through the ordering process, and it will take three or four days for the orders to cross the sea. Of course, in case exceptionally important and interesting items turn up, special measures, such as sending the order by cablegram, should be taken. Nevertheless, the distance and the time involved in processing orders are serious handicaps. It also seems to be a well established "secret" practice among the dealers to distribute their catalogs among their special patrons some time before they are sent to other, ordinary customers.

In order to meet these handicaps and also to operate library acquisition not merely on the basis of availability of 
materials but also on the basis of need, search lists are sent to some of the dealers who show willingness to go to the trouble of locating wanted materials for the library and whose satisfactory results substantiate their enthusiasm. Some librarians may fear that this practice of sending a search list for needed books to dealers would make them charge more for a wanted title. If the value of the wanted item is high, and if there is an urgent demand for it, it may be worth spending a few extra dollars. The bibliographer should have some knowledge of the comparative difficulty of acquiring certain items, and if a dealer has to make a special effort to get the needed materials he certainly deserves extra yen, so long as the prices remain within reasonable limits. Furthermore, in order to prevent any malpractice on the part of dealers, the bibliographer can warn them beforehand that whether or not the library purchases, the decisions will depend on the fairness of the prices quoted. He may ask them to send the quotations first and hold the materials until they receive a firm order.

To prearrange "blanket" orders with dealers is not advisable. In a research library on a limited acquisition fund, the bibliographer has to be selective and has to take the initiative. In view of the many publications issued each year, the practice of "blanket" orders with commercial dealers can be wasteful. The same criticism can be made of having an agent abroad. Unless the person designated as agent is thoroughly familiar with the nature of the collection and the acquisition policy, the materials he purchases can be useless. If the bibliographer keeps good relations with the dealers and enjoys their friendly cooperation, these practices will not be necessary. He can make an informal arrangement with some dealers, so that they will let him know immediately when they obtain materials of possible interest. For this, probably it will help to orient the dealers gradually to the characteristics, interests, and long range plan of the library. For the proper development of a collection, the bibliographer has to have the cooperation of the dealers. As in the case of any human relationship, sending courteous notes of appreciation for their efforts and findings and words of encouragement for future business transactions will certainly help in keeping the dealers' cooperation.

After a certain length of time and experience with formal orders, the bibliographer becomes familiar with the ability and specialties of each dealer. $\mathrm{He}$ will know which dealer is most efficient, for example, in locating search items, in securing governmental and institutional publications, in supplying back issues of journals, in handling special books on the Far East, and so forth. To each dealer accuracy and speed in filling the orders are stressed, since any mistake will be very costly and since, also, one semester has only fifteen weeks, so that if materials are not received quickly some of the research schemes may be upset. Usually the dealers do not have any difficulty in romanizing titles when they list them in the four copies of invoices, although the way some of the dealers misread Japanese titles is appalling.

It all depends on the dealer and the quality and quantity of the publications ordered, but usually it takes about one and a half to two months before the materials arrive. The materials received are checked with the invoices and forwarded to the bindery for accessioning, and the invoices to the main library for payment.

When the bibliographer receives requests from the faculty and knows of their interests, it is often rewarding to make a brief analysis of requests. We may call it a vertical and horizontal analysis: "vertical" meaning a checking on the present state of research in the field, important Japanese publications on the same theme, and the library's col- 
lection on the subject; "horizontal" meaning a study of the important publications in related fields. In this way the bibliographer can not only meet the immediate demand but also prepare materials to some extent for future needs. Again, in a specialized research library it is vitally important to keep close contact with the patrons and watch where their interest lies and how it develops, for this is the only way the bibliographer can meet the challenge, both present and future. Probably every library has found some time or another that although some books are ignored for some time, when researchers want them they have to have them immediately. The bibliographer should also be familiar with the contemporary trends in Japan and know who were and are outstanding scholars in the subjects of most moment to the faculty and the graduate students.

The focus of book selection by the bibliographer is primarily on the materials needed lor instructional and research purposes in Japanese studies, but he will need to consider the interests of the whole university community. For example, if the library is located on the West Coast, materials on or by the Japanese immigrants should be seriously considered. He will have to watch constantly for materials to keep some of the collections strong by supplementing with new materials, even if the interest in the collection at the present moment may not seem entirely to justify selection. For example, if the library has a strong collection on some aspect of Japanese literature, it will be quite logical to add new materials to it, even if there is little current interest. The bibliographer should never forget that the library serves the general library system and must keep materials ready to satisfy the interests of the whole community.

\title{
Copyright Problems
}

\author{
(Continued from page 222)
}

Should the number be limited to one in the case of limited editions and very expensive works? Should consideration be given to requiring additional copies for regional libraries, possibly set up as part of a quasi-federal system to provide security to our cultural product as well as to service it? Should a time period be fixed within which deposit must be made; should a penalty be provided for failure to deposit within that time and what should it be? Should deposit in advance of publication be permitted and encouraged?
There are other questions, and tentative answers to questions on the deposit system and on other elements of the copyright registration procedure will undoubtedly create additional questions. I hope I have been able to make clear at least the significant problems which we now have under consideration at the $\mathrm{I}$ ibrary of Congress; I hope also that you will take the opportunity afforded by this meeting to express your views regarding the desirable content of the deposit provisions of a revised copyright law.Rutherford D. Rogers.

COLLEGE AND RESEARCH LIBRARIES 